\title{
Vitamin D deficiency in early life accelerates Type 1 diabetes in non-obese diabetic mice
}

\author{
A. Giulietti $\cdot$ C. Gysemans $\cdot$ K. Stoffels $\cdot$ E. van Etten $\cdot$ B. Decallonne $\cdot$ L. Overbergh $\cdot$ R. Bouillon $\cdot$ C. Mathieu \\ Laboratory for Experimental Medicine and Endocrinology (LEGENDO), Catholic University of Leuven, UZ Gasthuisberg, \\ Onderwijs en Navorsing, Leuven, Belgium
}

\section{Abstract}

Aims/hypothesis. 1,25-dihydroxyvitamin $\mathrm{D}_{3}$, the active form of vitamin $\mathrm{D}$, prevents Type 1 diabetes in non-obese diabetic (NOD) mice. Epidemiological data show a threefold increase in human Type 1 diabetes when vitamin $\mathrm{D}$ deficiency was present in the first months of life. To evaluate whether a similar dietary deficiency affects diabetes incidence in NOD mice, we generated NOD mice with vitamin D deficiency in early life.

Methods. Breeding pairs of NOD mice, as well as their offspring (test mice), were kept in surroundings devoid of ultraviolet light and were fed a vitamin Ddepleted diet for 100 days. Mice were followed for 250 days.

Results. At 250 days, 35\% (12/35) male and 66\% $(22 / 33)$ female vitamin $\mathrm{D}$-deficient mice were diabetic compared to $15 \%(6 / 40, p=0.05)$ and $45 \%(13 / 29$, $p<0.01)$ of the control mice. At 100 days no difference in insulitis was seen, but more vitamin D-deficient mice were glucose intolerant. Higher IL1 expression was detected in islets of vitamin D-deficient mice and their peritoneal macrophages had an aberrant cytokine profile (low IL1 and IL6, high IL15). Thymus and lymph nodes of vitamin D-deficient mice contained less CD4 ${ }^{+} \mathrm{CD} 62 \mathrm{~L}^{+}$cells.

Conclusion/interpretation. Vitamin D status increases the expression of Type 1 diabetes in NOD mice. Our data in NOD mice, as well as human epidemiological data, point to the importance of preventing vitamin D deficiency in early childhood. Controlling this dietary factor could be an easy and safe way to reduce the incidence of Type 1 diabetes in subjects who are genetically at risk. [Diabetologia (2004) 47:451-462]

Keywords Vitamin D - Type 1 diabetes · NOD · Islets $\cdot$ Macrophage $\cdot$ Prevention $\cdot$ Rickets
Received: 27 July 2003 / Revised: 27 November 2003

Published online: 31 January 2004

C) Springer-Verlag 2004

C. Mathieu ( $)$

Laboratory for Experimental Medicine and Endocrinology (LEGENDO), Catholic University of Leuven, UZ Gasthuisberg, Onderwijs en Navorsing, Herestraat 49, 3000 Leuven, Belgium

E-mail: chantal.mathieu@med.kuleuven.ac.be

Abbreviations: $1,25(\mathrm{OH})_{2} \mathrm{D}_{3}, 1 \alpha, 25$-dihydroxyvitamin $\mathrm{D}_{3}$. $25(\mathrm{OH}) \mathrm{D}_{3}, 25$-hydroxyvitamin $\mathrm{D}_{3} \cdot \mathrm{BW}$, body weight $\cdot \mathrm{HBSS}$, Hanks' balanced salt solution - IP, interferon-inducible protein · IPGTT, intra-peritoneal glucose tolerance test $\cdot$ iNOS, inducible nitric oxide synthase $\cdot$ LPS, lipopolysaccharide $\cdot$ MCP, monocyte chemo-attractant protein - MIP, macrophage nflammatory protein - MLR, mixed lymphocyte reaction . NOD, non-obese diabetic · RPMI, Roswell Park Memorial Institute $\cdot \mathrm{UV}$, ultraviolet
Environmental factors have since long been implicated in the pathogenesis of autoimmune diseases such as Type 1 diabetes $[1,2]$. Candidates can be sought in diet, lifestyle, viral infections, but the clear northsouth gradient in prevalence of this and other autoimmune diseases in Europe has often suggested a role for sunlight as a modulator of autoimmunity [3, 4]. Also the observation that children with completely different genetic backgrounds often convert to the diabetes incidence of the country they live in, suggests that an environmental factor is involved $[5,6]$.

The discovery of the presence of receptors for the active form of vitamin $\mathrm{D}, 1 \alpha, 25$-dihydroxyvitamin $\mathrm{D}_{3}$ $\left(1,25(\mathrm{OH})_{2} \mathrm{D}_{3}\right)$ in several cells of the immune system, such as macrophages, dendritic cells, B lymphocytes and activated T lymphocytes has strengthened the idea that vitamin D might function as a physiological im- 
mune modulator [7]. In different animal models of autoimmune diseases administration of high doses of $1,25(\mathrm{OH})_{2} \mathrm{D}_{3}$ is able to prevent disease $[8,9,10,11$, $12]$ and in recent years both $T$ lymphocytes and antigen presenting cells, especially dendritic cells, have been identified as main targets for $1,25(\mathrm{OH})_{2} \mathrm{D}_{3}$ in the immune system [13].

Several epidemiological studies have shown a correlation between supplements of regular vitamin $D$ in early life and a protection against Type 1 diabetes [14, $15,16]$. In most studies the vitamin $\mathrm{D}$ status of the population at start was not clear, whereby the observed protection was either due to the restoration of a vitamin D-deficient status or to a true supplementary effect of extra vitamin $D$ being given to already vitamin D-sufficient children. In one study a subgroup of children was described with overt rickets in the first year of life [17]. In these children a threefold increase in diabetes prevalence in later life was observed. Since the effect of vitamin D deficiency was much greater than the effect of vitamin D supplementation in the other children, we hypothesised that mainly the vitamin D-deficient status in a genetically predisposed background might trigger autoimmunity, whereas high doses of active vitamin D hormone $\left(1,25(\mathrm{OH})_{2} \mathrm{D}_{3}\right)$ or an analogue would be needed to prevent the disease in vitamin D-sufficient subjects.

Our aim was to investigate the effects of vitamin D deficiency in utero and in early life on the prevalence of Type 1 diabetes in later life in an animal model of Type 1 diabetes, the NOD mouse. We discovered a clear increase in diabetes incidence in mice that were vitamin D deficient in the early weeks of life. Important changes in macrophage behaviour, namely a disturbed cytokine profile, might contribute to early betacell damage and a more aggressive presentation of the disease in genetically at risk subjects.

\section{Material and methods}

\section{Animals}

NOD mice have been bred in our animal facility since 1989, when they were obtained from Professor Wu (Beijing, China). At the time of the study, the diabetes incidence in our colony at the age of 250 days was $55 \%$ in female and $21 \%$ in male mice. With the purpose of inducing vitamin D deficiency in NOD mice, young (3-week-old) NOD male and female mice were kept in ultraviolet (UV) light-free surroundings and received a vitamin D-depleted diet containing $2 \%$ calcium and $1.25 \%$ phosphorus (TD 87095, Harlan Teklad Test Diets, Madison, Wis., USA). With this regime, the concentration of 25-hydroxyvitamin $\mathrm{D}_{3}\left(25(\mathrm{OH}) \mathrm{D}_{3}\right)$ dropped below detection limit in male and female mice $(<2.5 \mathrm{ng} / \mathrm{ml})$ by 8 weeks of age. After this was documented, breeding pairs were formed. Their offspring, the mice used in this study, were also kept in UV-free surroundings. After weaning, they received the same diet as their parents. Control mice were kept under similar conditions except their chow was supplemented with $2200 \mathrm{IU} / \mathrm{kg}$ vitamin D (control chow, Harlan Teklad Test Diets, Madison, Wis., USA), reaching the daily requirements for vitamin D. From 100 days of age, all mice were fed control chow.

Mice were screened two times weekly for diabetes onset by measuring glucose in urine (Clinistix, Bayer Diagnostics, Tarrytown, N.Y., USA) and in blood obtained from a tail vein (Glucocard, Menarini, Florence, Italy) in glucosuric mice. Mice were considered diabetic when having glucosuria and hyperglycaemia ( $>11.10 \mathrm{mmol} / \mathrm{l})$ on two consecutive days.

$\mathrm{C} 57 \mathrm{Bl} / 6$ and $\mathrm{BALB} / \mathrm{c}$ mice were purchased from Harlan CPB (Zeist, the Netherlands). All experiments were approved by the ethics commission from the KU Leuven.

Immune function of vitamin D-deficient and control NOD mice

Fluorescence-activated cell sorter (FACS) analysis of spleens, thymuses and lymph nodes. Spleens, thymuses and mesenteric lymph nodes were removed aseptically from diethylether anaesthetised control and vitamin D-deficient mice that were 100 days of age, and dispensed through a metal mesh in PBS to obtain single-cell suspensions. The following antibodies were used for standard staining: aCD3, aCD4, aCD8, aCD25, aCD62L, aB220, aCD11b, aCD11c, aCD54 mAbs (Caltag Laboratories, Burlingame, Calif., USA; PharMingen, Hamburg, Germany; Serotec, Oxford, UK). Cells were incubated for $30 \mathrm{~min}$ at $4^{\circ} \mathrm{C}$ with $10 \mu \mathrm{l}$ of PE-labelled $\mathrm{mAb}$ and $5 \mu \mathrm{l}$ FITC-labeled mAb. After washing twice, the cells were fixed with $1 \%$ paraformaldehyde. Analysis was done on a FACSort cytometer (Becton Dickinson, Dendermonde, Belgium). False positive cells were excluded by isotype-matched irrelevant $\mathrm{mAb}$ staining through similar procedures.

In vitro cell cultures. After aseptic removal, spleens and thymuses were placed in sterile Petri dishes containing Roswell Park Memorial Institute (RPMI) 1640 medium (Gibco, Paisley, Scotland, UK) and were disrupted by mechanical teasing. For mixed lymphocyte reaction (MLR) culture, splenocytes $\left(5 \times 10^{6} / \mathrm{ml}, 5 \times 10^{5} /\right.$ well $)$ from the responder population were co-cultured, after T-cell enrichment by a passage through nylon wool, with irradiated ( $30 \mathrm{~Gy},{ }^{60} \mathrm{Co}$ source) splenocytes from the stimulator population ( $\mathrm{C} 57 \mathrm{Bl} / 6$ mice) for 5 days at a $\mathrm{R} / \mathrm{S}$ ratio of $1: 1$. Cells were cultured in triplicate in flatbottomed 96-well microplates in complete culture medium (RPMI 1640 medium supplemented with $10 \% \mathrm{FCS}$ and $5 \times$ $10^{-5} \mathrm{~mol} / \mathrm{l} 2$-mercapto-ethanol) at $37^{\circ} \mathrm{C}$ in $5 \% \mathrm{CO}_{2}$ and air. Four days later, $1 \mu \mathrm{Ci}\left[{ }^{3} \mathrm{H}\right]$ thymidine (Radiochemical Centre Amersham, Buckinghamshire, UK) was added to each well. After incubation for another $18 \mathrm{~h}$, cells were harvested on glass filter paper using a semi-automated cell harvester (Skatron Instruments SA, Lier, Norway) and the incorporation of labelled nucleotide was calculated by liquid scintillation counting in a $\beta$-counter (Packard, Meriden, CT).

In parallel, thymocytes and splenocytes were cultured in flat-bottomed 96-well microplates at a concentration of $1 \times$ $10^{6}$ cells/ml in complete culture medium for anti-CD3 T-cell stimulation. Anti-CD3 mAb (Serotec) was added in a final concentration of $0.75 \mu \mathrm{g} / \mathrm{ml}$. Experiments were done in triplicate. For the last $18 \mathrm{~h}$ of a 72-h culture, cells were pulsed with $1 \mu \mathrm{Ci}\left[{ }^{3} \mathrm{H}\right]$ thymidine. The cells were then harvested and the incorporated radioactivity was assayed by liquid scintillation counting.

Results of T-cell proliferation assays are expressed as stimulation index $(\mathrm{SI}=$ mean counts per $\min (\mathrm{cpm})$ of stimulated cells-mean cpm of non-stimulated cells/mean cpm of nonstimulated cells $) \pm$ SEM. 
In vitro macrophage function. For analysis of macrophage function, whole blood and peritoneal macrophages were used in parallel tests. Peritoneal macrophages were harvested as described previously [7]. Briefly, mice were anaesthetised with diethylether and injected intraperitoneally with $10 \mathrm{ml}$ of RPMI 1640 medium. After $1 \mathrm{~min}$, medium was collected from the peritoneum with an $18 \mathrm{~g}$ needle into a sterile tube. Macrophage purity reached above $90 \%$ when assessed by flow cytometry, using the mAb CD11b (Serotec). Cells were counted and suspended to a concentration of $1 \times 10^{6}$ cells $/ \mathrm{ml}$ in complete culture medium. For macrophage chemotactic evaluation, the ability of binding casein was measured as described previously [7]. Chemotactic capacity was expressed as percent of fluoresceinpositive cells. Respiratory oxidative burst capacity was evaluated using a commercial kit (BURTTEST, Orpegen Pharma, Heidelberg, Germany). The test was carried out by following the instructions from the manufacturer. Results were expressed as percentage of fluorescein-positive cells. Parallel tests were done to assess macrophage function in whole blood. Around $1 \mathrm{ml}$ of blood was collected from ether-anaesthetised mice by heart puncture. Chemotaxis was evaluated in a similar manner as was done for peritoneal macrophages. In addition, formylNle-Leu-Phe-Nle-Tyr-Lys fluorescein derivative (fnlpntl) was also used to evaluate chemotaxis capacity of neutrophils, as described before [7]. Phagocytosis capacity was measured by flow cytometry using PHAGOTEST (Orpegen Pharma). The test was done following the instructions given by the manufacturer.

For cytokine analysis, peritoneal macrophages were suspended in RPMI 1640 and 10\% FCS to reach a final concentration of $2.5 \times 10^{5}$ cells per $\mathrm{ml}$ and were stimulated either with LPS (10 $\mu 1 / \mathrm{ml}$, Sigma, St. Louis, Mo., USA) or with LPS plus IFN $\gamma$ (100 U/ml, Peprotech, Rocky Hill, N.J., USA). Cells were incubated for either $6 \mathrm{~h}$ or $24 \mathrm{~h}$. For mRNA analysis, cells were harvested and used immediately for RNA extraction. Until use, mRNA was stored at $-80^{\circ} \mathrm{C}$.

\section{Calcium and bone parameters in vitamin D-deficient} and control NOD mice

At 100 and at 250 days of age, blood was collected by heart puncture under diethylether anaesthesia. Serum samples for calcium, osteocalcin, $25(\mathrm{OH}) \mathrm{D}_{3}$ and $1,25(\mathrm{OH})_{2} \mathrm{D}_{3}$ were stored at $-20^{\circ} \mathrm{C}$ prior to their measurement. At the same time, a tibia was collected and stored at $-20^{\circ} \mathrm{C}$ for measurements of bone calcium content. Calcium (in serum and tibia) was measured using a photo-colorimetric method (Sigma Chemical, St. Louis, Mo., USA). Osteocalcin was measured by an in-house RIA as described [18]. Serum $25(\mathrm{OH}) \mathrm{D}_{3}$ and $1,25(\mathrm{OH})_{2} \mathrm{D}_{3}$ were measured by ELISA (IDS Boldon, Tyne \& Wear, UK) and RIA (ICN Biomedicals, Costa Mesa, Calif., USA) respectively.

Beta-cell function in vitamin D-deficient and control NOD mice

Preparation and culture of pancreatic islets. Islets were isolated from the pancreas of male and female vitamin D-deficient and control NOD mice as described [19]. Briefly, islets were isolated from the pancreas by collagenase digestion in HBSS followed by hand picking under a stereomicroscope.

For insulin secretion and content, freshly isolated islets (five islets in each well) were incubated in $300 \mu$ l Krebs-Ringer bicarbonate buffer with $16 \mathrm{mmol} / \mathrm{l}$ HEPES for $2 \mathrm{~h}$ in the presence of various $\mathrm{D}(+)$ glucose concentrations $(0-30 \mathrm{mmol} / \mathrm{l})$. After incubation, insulin was measured in both islet supernatant and homogenate by ELISA (Mercodia, Uppsala, Sweden).

For mRNA analysis, islets from at least five animals per group were prepared from 2- to 12-week-old male and female control and vitamin D-deficient NOD mice as well as from 4-week-old male and female BALB/c mice. Two independent experiments were done. Islets were frozen in liquid nitrogen and stored at $-80^{\circ} \mathrm{C}$ until use.

Intra-peritoneal glucose tolerance test (IPGTT). Glycaemia was measured in tail vein blood using a glucometer (Glucocard, Menarini, Florence, Italy) before and after (5, 15, 30, 60 and $120 \mathrm{~min}$ ) an intra-peritoneal injection of $3 \mathrm{~g} \mathrm{D}(+)$ glucose monohydrate $/ \mathrm{kg} \mathrm{BW}$, dissolved in sterile PBS.

\section{Histology}

Pancreases from all experimental groups at 100 and 250 days were embedded in optimal cutting temperature (OCT) medium, snap-frozen in 2-methyl-butane $99 \%+$ chilled in liquid nitrogen and stored at $-80^{\circ} \mathrm{C}$ until processing [20]. 5- $\mu \mathrm{m}$ cryostat sections were stained with Mayer's haematoxylin and eosin. By light microscopy, insulitis was scored by an experienced blinded observer as follows: 0 , islets free of insulitis; 1 , islets with peri-insulitis; 2 , islets with lymphocyte infiltration in less than $50 \%$ of the area; 3 , islets with lymphocyte infiltration in more than $50 \%$ of the area; 4 , islets with lymphocyte infiltration in more than $90 \%$ of the area and severe beta-cell destruction.

Real time reverse transcriptase polymerase chain reaction (RT-PCR) analysis of various cell types

Total RNA was extracted using the available commercial High Pure RNA isolation kit (Roche Diagnostics Indianapolis, Ind., USA) for peritoneal macrophages and islets and the SV total RNA isolation System (Promega, Madison, Wis., USA) for pancreases. cDNA synthesis was done as described [21, 22]. Each RT-PCR reaction contained $0.5 \mu \mathrm{l}$ cDNA sample, $50 \mathrm{mmol} / \mathrm{l} \mathrm{KCl}, 10 \mathrm{mmol} / \mathrm{l}$ Tris- $\mathrm{HCl}$ (pH 8.3), $10 \mathrm{mmol} / \mathrm{l}$ EDTA, 60 nmol/l Passive Reference $1200 \mu \mathrm{mol} / \mathrm{l}$ dNTPs, 3-9 $\mathrm{mmol} / \mathrm{l} \mathrm{MgCl}_{2}, 100$ to $900 \mathrm{nmol} / \mathrm{l}$ of each primer, $100 \mathrm{nmol} / \mathrm{l}$ TaqMan probe, and $0.625 \mathrm{U}$ AmpliTaq Gold. PCR amplifications were done in an ABI Prism 7700 SDS (Applied Biosystems, Foster City, Calif., USA) for $10 \mathrm{~min}$ at $94^{\circ} \mathrm{C}$ followed by a total of 40 to 45 two-temperature cycles. The primer sequences used here; IL1 $\beta$, IL4, IL6, IL12 4 40 , IL15, iNOS, TNF $\alpha$, TGF $\beta$, IFN $\gamma$, MIP3 $\alpha$, MCP1, IP10, fractalkine and $\beta$-actin are described elsewhere [21]. Quantification was made using a standard curve (cDNA plasmids) as described [22]. Results were expressed as the ratio of copy number target to copy number $\beta$-actin.

\section{Statistical analysis}

Statistical analyses were made using the following tests when appropriate: Kaplan Meier Survival test, log-rank test, chisquared test, two-way analysis of variance (ANOVA) test (with post Student's $t$ tests), the area under the curve (AUC) with ANOVA test, the Mann-Whitney U test and the Student's $t$ test. A $p$ value .05 (or in case of multiplicity of testing, 0.01) was considered to be significant. The software NCSS 2000 (Kaysville, Utah) was used. 
Table 1. Metabolic parameters at 100 and 250 days of age in mice

\begin{tabular}{|c|c|c|c|c|c|}
\hline & & $\begin{array}{l}\text { D-deficient } \\
\text { NOD male }\end{array}$ & $\begin{array}{l}\text { Control } \\
\text { NOD male }\end{array}$ & $\begin{array}{l}\text { D-deficient } \\
\text { NOD female }\end{array}$ & $\begin{array}{l}\text { Control } \\
\text { NOD female }\end{array}$ \\
\hline Serum calcium (mg/dl) & $\begin{array}{l}100 d \\
250 d\end{array}$ & $\begin{array}{l}9.1 \pm 0.5(n=14) \\
9.5 \pm 0.4(n=13)\end{array}$ & $\begin{array}{l}9.5 \pm 0.3(n=7) \\
8.9 \pm 0.5(n=10)\end{array}$ & $\begin{array}{l}10.0 \pm 0.4(n=14) \\
10.5 \pm 0.4(n=11)\end{array}$ & $\begin{array}{r}9.4 \pm 0.5(n=5) \\
10.2 \pm 0.2(n=11)\end{array}$ \\
\hline $25(\mathrm{OH}) \mathrm{D}_{3}(\mathrm{ng} / \mathrm{ml})$ & $\begin{array}{l}100 d \\
250 d\end{array}$ & $\begin{array}{l}9.6 \pm 1.6(n=11)^{\mathrm{a}} \\
54.2 \pm 2.3(n=5)\end{array}$ & $\begin{array}{l}73.9 \pm 6.2(n=8) \\
56.8 \pm 8.4(n=5)\end{array}$ & $\begin{aligned} 7.3 \pm 1.3(n=11)^{\mathrm{a}} \\
52.8 \pm 2.8(n=5)\end{aligned}$ & $\begin{array}{l}56.8 \pm 7.8(n=5) \\
43.9 \pm 2.5(n=5)\end{array}$ \\
\hline Osteocalcin (ng/ml) & $\begin{array}{l}100 d \\
250 d\end{array}$ & $\begin{array}{l}61.6 \pm 4.1(n=10) \\
29.6 \pm 5.0(n=8)\end{array}$ & $\begin{array}{l}67.2 \pm 4.1(n=6) \\
25.6 \pm 2.6(n=8)\end{array}$ & $\begin{array}{l}72.8 \pm 8.3(n=10) \\
58.1 \pm 11.1(n=5)\end{array}$ & $\begin{array}{l}82.1 \pm 7.8(n=5) \\
52.1 \pm 7.3(n=9)\end{array}$ \\
\hline
\end{tabular}

Data expressed as means \pm SEM

a $p<0.00001$ compared to control mice of the same sex

\section{Results}

Evaluation of vitamin D deficiency in NOD mice

A significant difference in body weight was observed between NOD mice exposed in utero to either normal or low vitamin $\mathrm{D}$ when measured at 2 weeks of age $(6.56 \pm 0.63$ vs $3.85 \pm 0.56 \mathrm{~g}$ in female mice, $p<0.0001$ and $6.81 \pm 0.57$ vs $4.08 \pm 0.49 \mathrm{~g}$ in male mice, $p<0.0001$ ), suggesting that vitamin $\mathrm{D}$ deficiency induced a growth retardation in utero or during lactation. After weaning however, no difference could be seen between control and vitamin D-deficient mice within male and female mice (Fig. 1).

At 100 days of age, no differences were noted in serum calcium, osteocalcin or bone calcium between control and vitamin D-deficient NOD mice (Table 1). Serum $25(\mathrm{OH}) \mathrm{D}_{3}$ values were dramatically decreased in vitamin D-deficient animals of both sexes (Table 1). Also the concentration of the activated form of vitamin $\mathrm{D}, 1,25(\mathrm{OH})_{2} \mathrm{D}_{3}$, was very low in vitamin D-deficient mice $(19.7 \pm 2.4$ vs. $78.4 \pm 16.9 \mathrm{pg} / \mathrm{ml}$ in control mice, $p<0.05)$.

At 250 days of age, when vitamin D was already restored in the diet since 100 days of age, all metabolic parameters returned to normal, confirming the transient nature of the vitamin D deficiency (Table 1).

Effect of vitamin D deficiency in early life on insulitis and diabetes incidence in NOD mice

No difference was observed in insulitis prevalence, with insulitis already being present in 9/10 and 9/9 vitamin $\mathrm{D}$-deficient male and female NOD mice versus 9/9 and 9/10 control male and female mice (NS) at 100 days. Also the severity of insulitis was comparable between the groups (score $1.8 \pm 0.3$ and $2.7 \pm 0.3$ in vitamin $\mathrm{D}$-deficient male and female mice respectively, vs score $2.7 \pm 0.4$ and $2.9 \pm 0.2$ in control mice, NS). At 250 days of age, this severity increased to

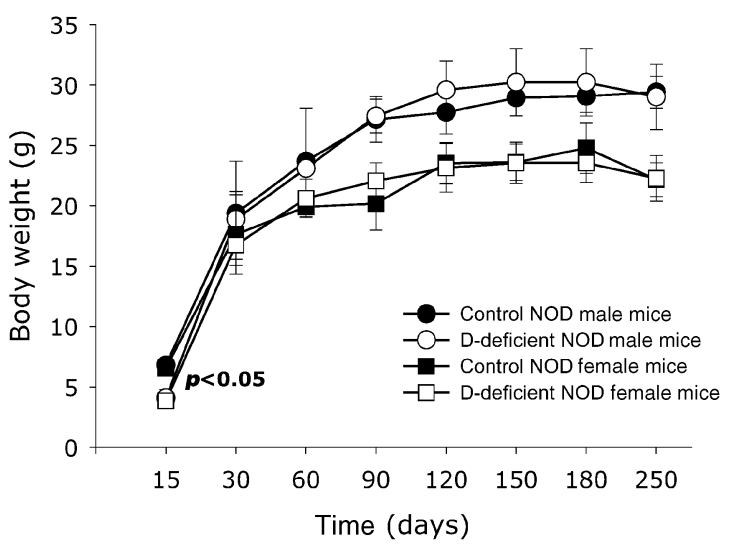

Fig. 1. Body weight of vitamin D-deficient and control NOD mice. Body weight from vitamin D-deficient and control NOD mice were evaluated over a period of 250 days. Note that vitamin D-deficient mice are smaller at 2 weeks of age while no difference can be seen after 1 month. Data expressed as means \pm SEM. At least ten mice per group were weighed at each time point

score $3.9 \pm 0.4$ and $3.6 \pm 0.9$ in vitamin $\mathrm{D}$-deficient male and female mice respectively, vs score $3.7 \pm 0.7$ and $4.0 \pm 0.0$ in male and female control mice, with insulitis present in $8 / 8$ and $9 / 9$ male and female vitamin D-deficient mice respectively vs $9 / 9$ and $8 / 8$ in male and female control mice (NS).

Diabetes presentation was more aggressive in mice with vitamin D deficiency in early life, with an earlier onset and a higher final incidence (Fig. 2). While control male mice developed diabetes from 127 days of age (mean of 152 days), reaching a maximum incidence of $15 \%$ (6 out of 40 mice) by 250 days of age, NOD male mice with vitamin D deficiency in early life started developing diabetes at 71 days (mean 113 days, $p<0.0005$ ), reaching an incidence of $35 \%$ (12 out of 35 mice) at 250 days of age ( $p=0.05)$. A similar phenomenon occurred in female mice, where the controls developed diabetes from 85 days of age (mean 127 days) reaching $45 \%$ (13 out 29 mice) by 250 days of age and vitamin D-deficient mice had diabetes from 61 days of 


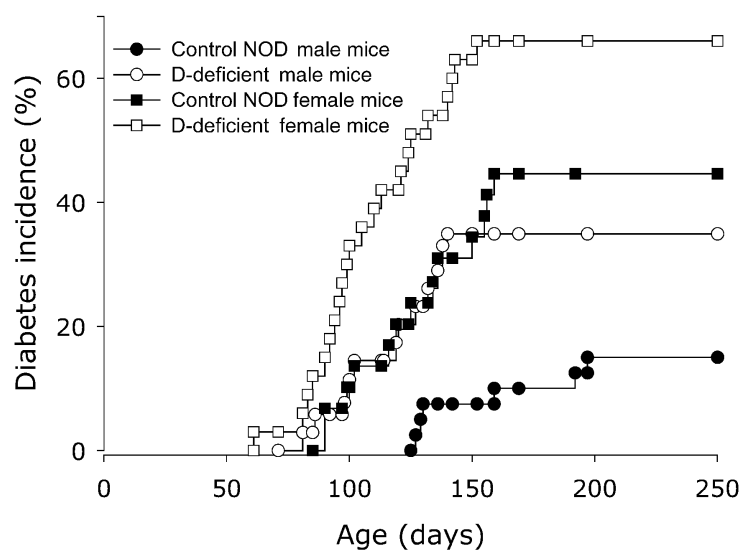

Fig. 2. Diabetes incidence in vitamin D-deficient and control NOD mice. Diabetes incidence is clearly higher in NOD mice that were submitted to vitamin D deficiency in utero and early life. A higher incidence and an earlier disease onset were present in the vitamin D-deficient mice. Vitamin D-deficient NOD male mice reached an incidence of $35 \%$ (12 out of 35 mice) against $15 \%$ (6 out of 40$)$ of control NOD male mice $(p=0.05)$. Vitamin D-deficient NOD female mice presented the highest incidence reaching $66 \%$ (22 out of 33 ) while control NOD female mice appear with $45 \%$ (13 out of $29, p<0.01$ ). Statistically significant differences were obtained by Kaplan Meierlife table analysis (log-rank test) and chi-square test

age (mean 108 days, $p<0.0005$ ) reaching 66\% (22 out of 33 mice) at the end of the study $(p<0.01)$.

Immune function of vitamin-D deficient and control NOD mice

Phenotyping of immune cells. Thymic composition was only slightly altered in vitamin D-deficient mice at 100 days of age, with clearly lower amounts of single positive CD4 (in females) and CD8 cells (in males and female mice) and higher amounts of double positive CD4/CD8 cells (in females) (Table 2). Of interest, $\mathrm{CD} 4{ }^{+} \mathrm{CD} 62 \mathrm{~L}^{+}$cells, claimed to be regulator cells, were scarcer in thymuses of vitamin D-deficient mice, however only reaching the level of significance in female mice $(p<0.05$ vs control female mice).

Cellularity was markedly decreased in the spleens of both female and male vitamin $\mathrm{D}$-deficient mice $(p<0.05)$, but in the peripheral murine system only subtle difference could be detected between vitamin D-deficient and control NOD mice (Table 2). In mesenteric lymph nodes again lower counts of $\mathrm{CD} 4{ }^{+} \mathrm{CD} 62 \mathrm{~L}^{+}$cells were found $(p<0.05$ in female mice), while a clearly higher amount of $\mathrm{CD}^{+}$cells were present $(p<0.05$ in males and female mice). Ex vivo analysis of the surface marker profile of CD11 ${ }^{+}$ dendritic cells in thymus, spleen and lymph nodes did not show any differences.

Analysis of $T$ and B lymphocyte function. No severe impairment in T-cell proliferation was observed. Splenocytes from vitamin $\mathrm{D}$-deficient mice proliferated to

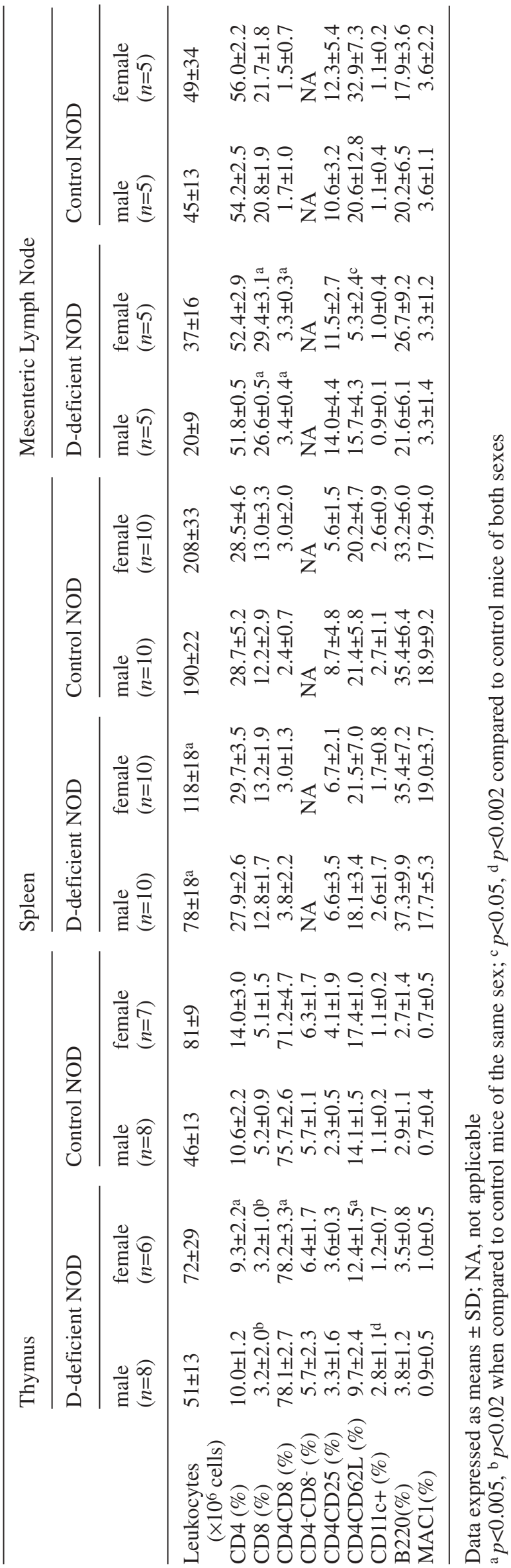




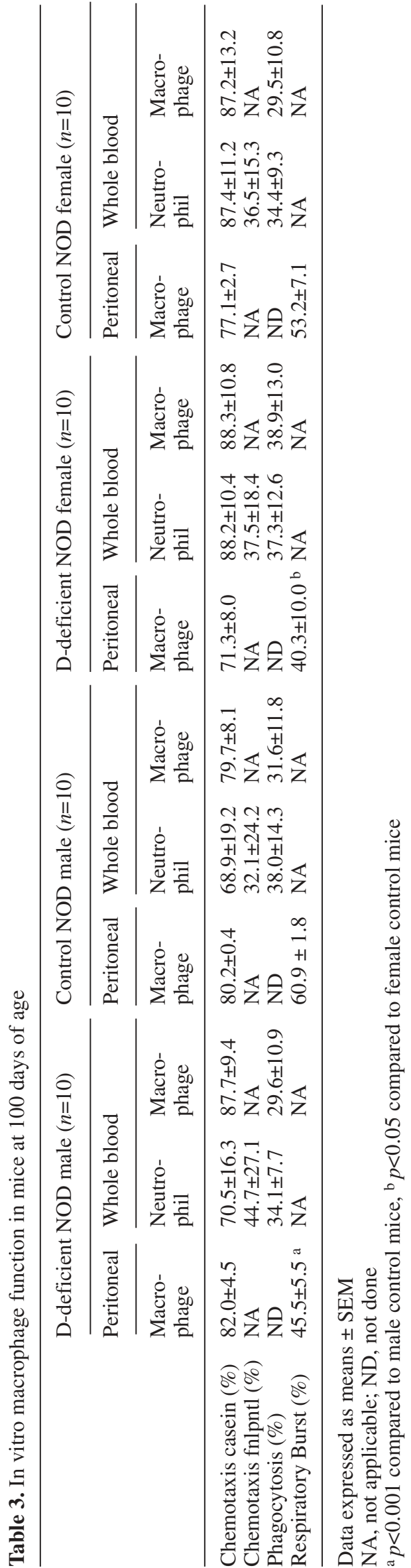

the same extent to different stimuli such as allogeneic lymphocytes and anti-CD3. Of note, however, is the somewhat lower SI in MLR in vitamin D-deficient mice. Vitamin D-deficient mice had a SI of $34.0 \pm 15.2$ in male $(n=4)$ and $57.3 \pm 23.2$ in female mice $(n=4)$, whereas in control NOD mice, SI was $72.3 \pm 15.4$ and $118.5 \pm 17.4$ in male $(n=4)$ and female mice $(n=4)$ respectively, but this value did not reach statistical significance.

No difference in antibody profile could be detected in 100-day-old vitamin D-deficient and control mice $\left(\mathrm{IgG}_{1}\right.$ and $\left.\mathrm{IgG}_{2 \mathrm{a}}\right)$.

In vitro analysis of macrophage function. No differences in chemotactic or phagocytic capacity were found between the groups (Table 3). The ability to form free radicals was, however, decreased in peritoneal macrophages from vitamin D-deficient mice (Table 3). Exposing peritoneal macrophages to LPS or a mixture of LPS and IFN $\gamma$ further highlighted defects present in the macrophages of the vitamin D-deficient mice. Indeed, a severe deficiency in IL1 (Fig. 3a) and IL6 (Fig. 3b) response to these stimuli was observed, whereas the IL15 (Fig. 3c) response was greatly enhanced. No differences were observed for iNOS (Fig. 3d), TNF $\alpha$, TGF $\beta$ or IL $12_{\mathrm{p} 40}$.

Beta-cell function in vitamin D-deficient and control NOD mice

In order to detect impaired glucose tolerance at early age, IPGTTs were done at 100 days of age in nondiabetic mice (Fig. 4). Basal glycaemia (0 min) was comparable between vitamin D-deficient and control mice $(5.37 \pm 0.59$ vs $6.63 \pm 0.56 \mathrm{mmol} / 1$ in males and $5.53 \pm 0.69$ vs $5.41 \pm 0.88 \mathrm{mmol} / \mathrm{l}$ in females, NS). After the intra-peritoneal glucose challenge a different response pattern was observed between the two groups in both sexes $(p<0.05$ and $p<0.05$ for female and male mice, respectively), reaching severely impaired values mainly in male mice (Fig. 4).

When isolated islets from 100-day-old mice were exposed to an in vitro glucose challenge $(20 \mathrm{mmol} / \mathrm{l})$, no defect in either insulin content or secretion could be detected in the vitamin D-deficient mice compared with both male and female control mice.

Intra-islet cytokine and chemokine expression

Whole pancreases were analysed at 100 days of age to assess cytokine expression profile. No difference in expression of IFN $\gamma$ and IL4 were observed between vitamin D-deficient and control NOD mice.

Chemokine expression was analysed in pancreatic islets from 2- to 12-week-old vitamin D-deficient and control NOD mice matched for sex. As previously 
a

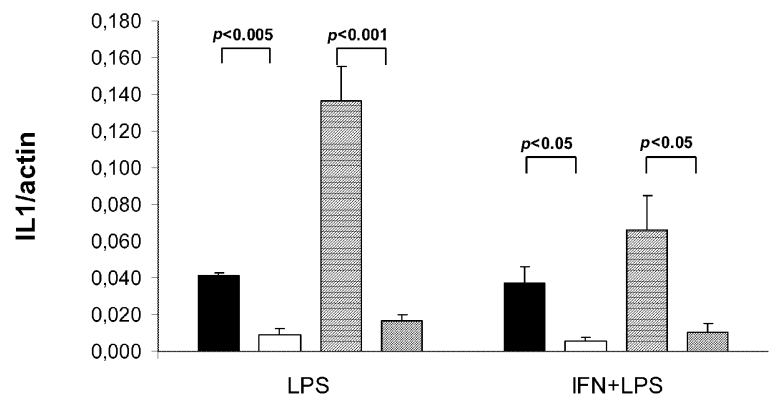

b

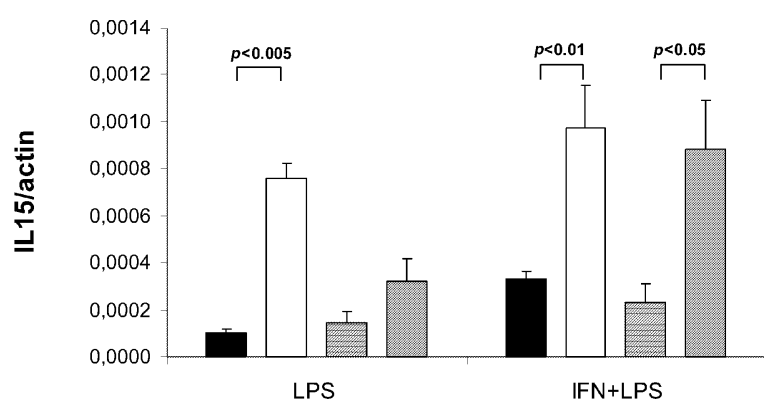

Fig. 3. Cytokine mRNA expression in peritoneal macrophages. Real-time RT-PCR was used to determine cytokine mRNA expression in peritoneal macrophages harvested from vitamin $\mathrm{D}$ deficient and control NOD mice. Cells were incubated for $6 \mathrm{~h}$ and challenged either with LPS or with LPS plus IFN $\gamma$. Data is expressed as mean of target copies divided by $\beta$-actin copies \pm
C

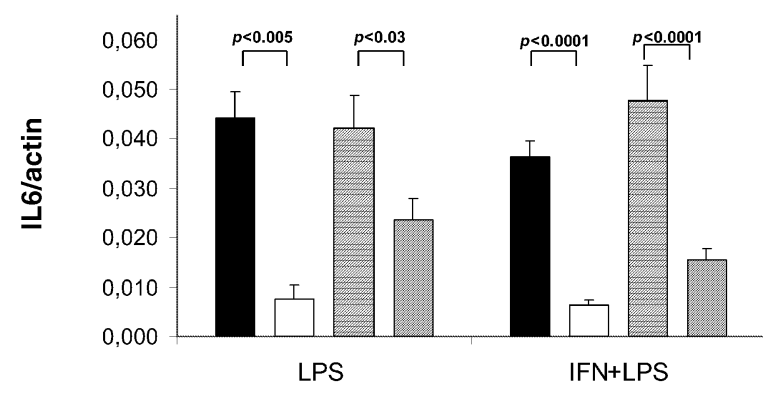

d

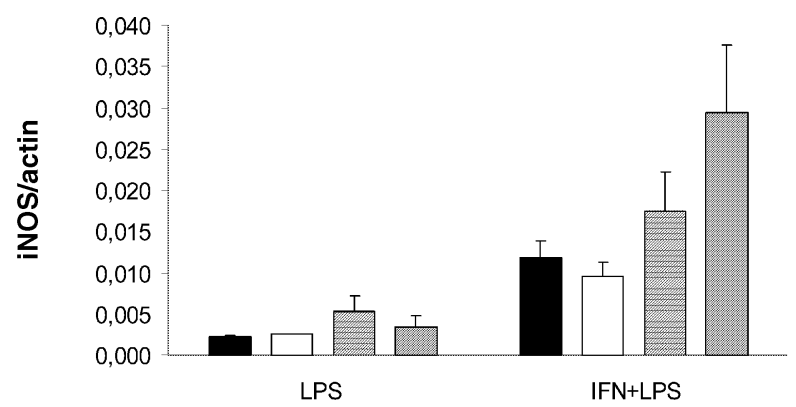

SEM. Aat least five mice were used to compose each group. White bar Control NOD male, black bar Vitamin D-deficient NOD male, hatched bar Control NOD female, grey bar Vitamin D-deficient NOD female. (a) IL1 expression; (b) IL6 expression, (c) IL15 expression, (d) iNOS expression

\section{Male mice}

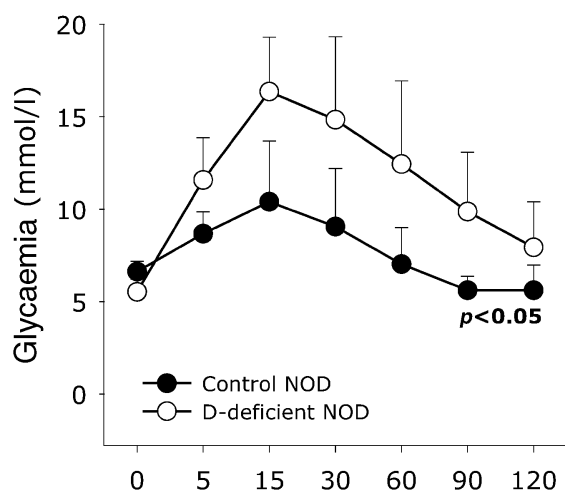

Female mice

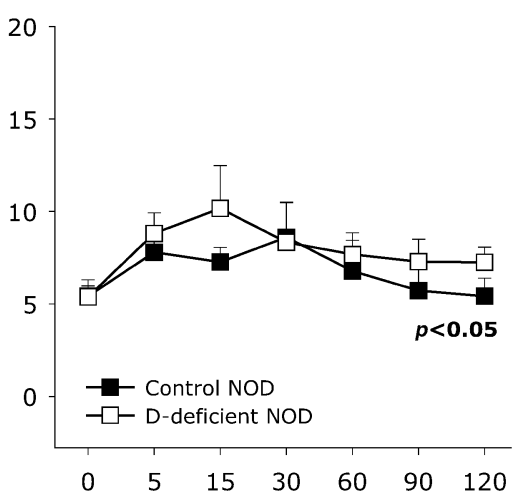

Time (min)

Fig. 4. IPGTTs in vitamin D-deficient and control NOD mice. Mice were challenged intra-peritoneally with $3 \mathrm{~g}$ of glucose and glycaemia was accessed at 5, 15, 30, 60 and $120 \mathrm{~min}$. Basal glycaemia was comparable between the groups while glucose intolerance was observed in vitamin D-deficient mice in the minutes subsequent. Data expressed as means \pm SEM observed, control male and female NOD mice showed a gradual increase in expression of pro-inflammatory cytokines (IL1 $\beta$ and IFN $\gamma$ ) and chemokines (MCP1, IP10 and MIP3 $\alpha$ ), coinciding with the increase in insulitis score (Fig. 5). For all cytokines and chemokines tested, mRNA expression levels were increased in vitamin D-deficient as well as in control NOD mice as compared to the BALB/c controls $(p<0.05)$, except for fractalkine, where an already known NOD defect was confirmed. When comparing vitamin D-deficient and 
Male mice
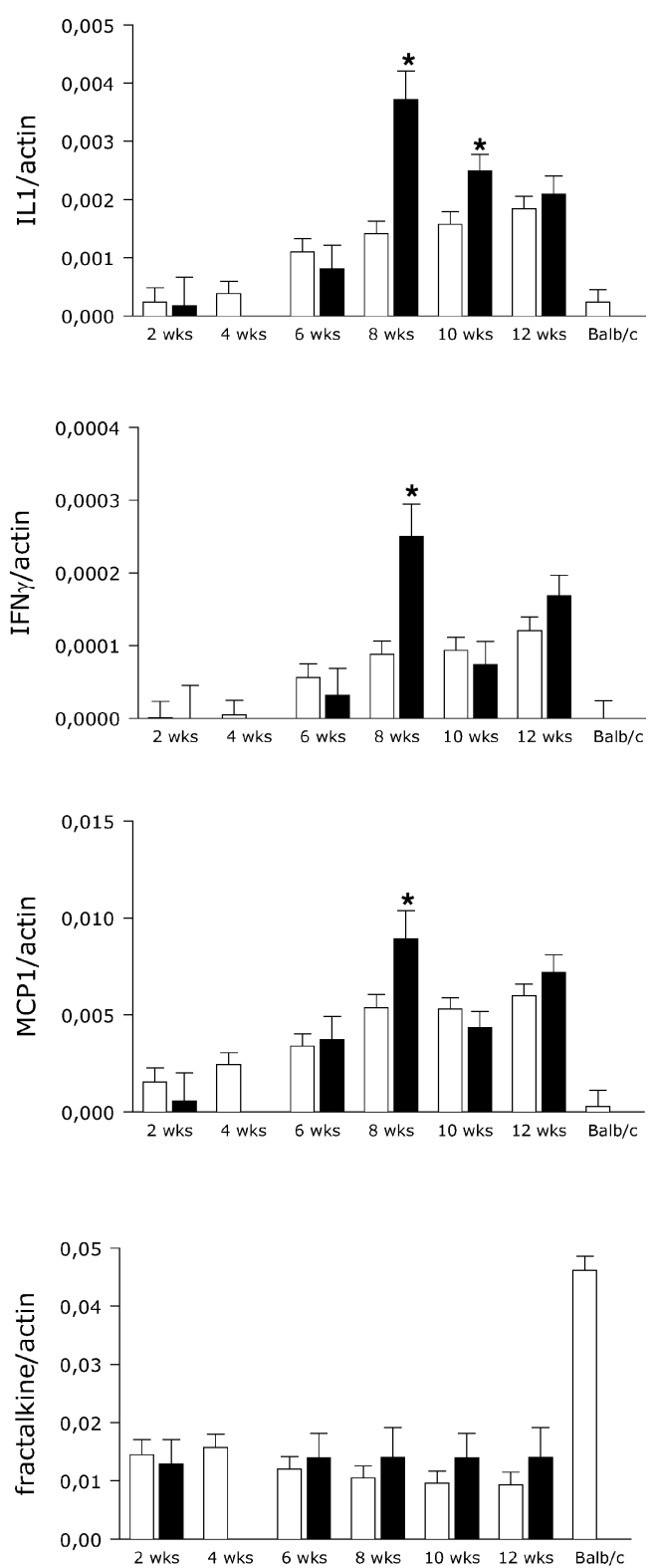

Fig. 5. Intra-islet cytokine and chemokine expression. Realtime RT-PCR was used to assess mRNA expression of cytokines and chemokines in isolated islets of vitamin D-deficient and control NOD mice $(n \geq 5)$. Data is expressed as mean of target copies divided by $\beta$-actin copies \pm SEM from two independent experiments. ${ }^{*} p<0.05$, when vitamin $\mathrm{D}$-deficient mice is compared to control NOD mice. Black bar Control NOD; white bar Vitamin D-deficient NOD

control NOD mice, IL1 levels were up-regulated from 6 and 8 weeks of age in the rachitic groups. In general, no major differences were noted for IFN $\gamma$ and chemokine (MCP1 and fractalkine) mRNA expression in islets between vitamin D-deficient and control mice (Fig. 5). Also no difference was seen in IP10 and MIP3 $\alpha$ expression levels between vitamin D-deficient and control NOD mice.
Female mice
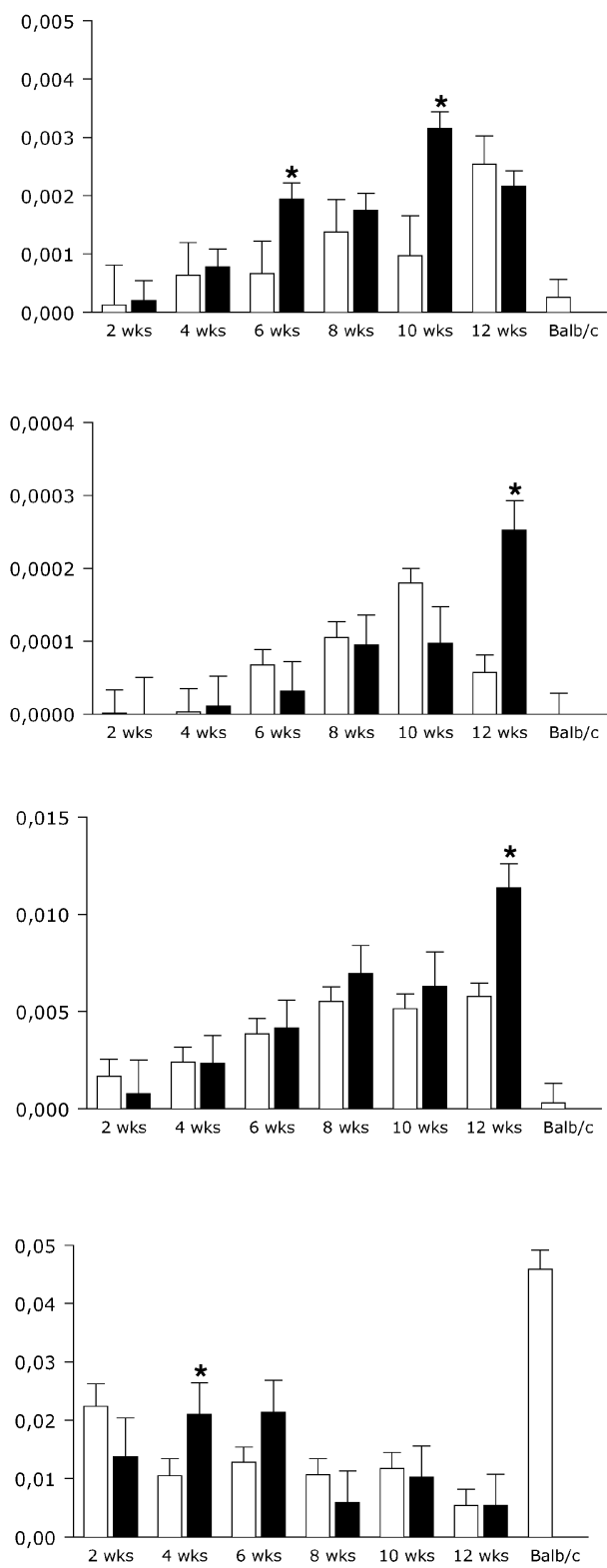

Discussion

The presentation of Type 1 diabetes in humans as well as in NOD mice is dependent on an interplay between genetic and environmental factors. Several studies point towards vitamin $\mathrm{D}$ as being one of the modulating environmental factors [17]. Our study shows that in NOD mice that are genetically at risk of developing Type 1 diabetes, vitamin $\mathrm{D}$ deficiency in early life leads to a more aggressive presentation of the disease, with an earlier onset, and a higher final incidence of the disease. We created a model of subtle vitamin D deficiency in early life, with only a measurable vitamin $\mathrm{D}$ deficiency in blood, but no effect on calcium concentration in serum or bone calcium content. We deliberately chose this model of temporary slight vitamin D deficiency, since this is most proba- 
bly the reflection of the vitamin D status in many infants and small children, even in areas with high exposure to sunlight, since infants often are shielded from UV B exposure. Although vitamin D supplements are advised in many countries, the application is far from strictly controlled and many times, these supplements are omitted or administered irregularly. Nutritional rickets that has never been completely eradicated in some countries and may be reappearing in industrialised countries [23] could be one of the factors contributing to the higher incidence of Type 1 diabetes in the past two decades [24]. A recent Finnish epidemiological study [17] has shown a clear association between overt rickets in the first year of life in this genetically high-risk population and the development of diabetes in later life. We induced vitamin D deficiency in early life in a NOD colony with an intermediate risk for diabetes, anticipating an increase in diabetes incidence. The vitamin $\mathrm{D}$ deficiency in our mice was already present in utero, since the parents of the mice studied were already put on a vitamin $\mathrm{D}$-free diet from 3 weeks of age. This vitamin D-deficient status was then maintained until 100 days of age as shown by the low concentration of $25(\mathrm{OH}) \mathrm{D}_{3}$. This vitamin $\mathrm{D}$ deficiency in early life in the genetically predisposed NOD mouse was accompanied by a more aggressive presentation of Type 1 diabetes. Diabetes onset was earlier and final incidence was increased in females as well as in the more diabetes-resistant male mice. Switching mice to a normal diet at 100 days of age avoided the development of overt rickets in mice with disturbances in bone and calcium homeostasis. In adult life however the higher aggressiveness of the disease persisted and a higher total incidence was registered in both sexes. At 250 days of age, when the study was terminated, no calcium or bone abnormalities could be found in the previously vitamin D-deficient mice.

Analysis of the immune system of the vitamin Ddeficient mice at 100 days of age, time when animals were switched to normal food, showed major abnormalities in macrophage behaviour. The differences were, however, not situated in impaired phagocytosis or chemotaxis, previously observed in severe rickets $[7,25,26,27]$. The near normal phagocytic and chemotactic capacity confirms again the relevance of our model, where we did not create severely rachitic mice, but only induced a vitamin deficiency frequently observed in children. This deficiency resulted, however, in an impressively disturbed inflammatory behaviour of the NOD macrophages, with lower respiratory burst capacity and a disturbed cytokine profile with increased IL15 mRNA expression and extremely low IL1 and IL6 expression. This low expression of IL1 and IL6 is in agreement with previous reports in rachitic animals [28]. Abnormalities in macrophages have been implicated in the pathogenesis of Type 1 diabetes, with these cells being one of the first to be present in insulitis $[29,30]$. An abnormal inflammatory profile of these cells could lead to aspecific beta-cell damage, thus triggering a beta-cell destructive cascade. Previously, NOD mice were shown to have severe defects in their macrophage differentiation and function [31]. In this context, NOD macrophages are known to have a defect in IL1 expression upon stimulation with LPS [32]. Vitamin D-deficient mice generated in this study presented with an even bigger defect in IL1 and also IL6 secretion, probably due to a defect in macrophage differentiation in NOD mice lacking vitamin D in the diet. High IL15 mRNA expression on the other hand possibly contribute to the survival of autoreactive $\mathrm{T}$ lymphocytes [33], and could thus be implicated in the worsening of the disease. These abnormal cytokine profiles of macrophages from vitamin D-deficient NOD mice might play a crucial role in the higher incidence of Type 1 diabetes in vitamin $\mathrm{D}$-deficient mice. A characteristic of badly differentiated NOD macrophages is the fact that they produce a low amount of IL1 when exposed to stimuli such as LPS in vitro, but accumulate locally in the islets where they produce inappropriately high amounts of cytokines in the presence of apoptotic cells that should have been cleared silently [34]. Vitamin D deficiency clearly aggravated this macrophage maturation problem.

In accordance with the abnormal macrophage cytokine profile, we found high pro-inflammatory cytokine expression locally in the islets of vitamin Ddeficient NOD mice compared to control NOD mice. Recently we and others have observed that in islets of NOD mice, but also in pure rat or human beta cells, inflammatory cytokines can trigger the expression of chemokines, thus probably contributing to the accumulation of more immune cells in the islets and precipitating beta-cell destruction [35, 36, 37]. In our study, no significant differences could be observed in local islet chemokine expression between vitamin Ddeficient and control mice. However, the observation of a higher intra-islet IL1 expression taken together with the histological observation of a similar degree of insulitis in control and vitamin D-deficient mice, suggests a higher activation status of the infiltrating immune cells and thus a more aggressive presentation of the disease.

Vitamin D deficiency also affected lymphocyte profiles, with clearly lower counts of splenocytes in vitamin D-deficient mice and a disturbed thymocyte profile. In the thymus, lower percentages of single positive CD8 $\mathrm{T}$ lymphocytes and higher numbers of double positive CD4/CD8 cells were present, possibly indicating a maturational problem. Of interest are the lower counts of $\mathrm{CD}^{+}{ }^{+} \mathrm{CD} 62 \mathrm{~L}^{+}$lymphocytes in thymus as well as in peripheral lymph nodes. Vitamin D-deficiency seems to further decrease the number of these cells in the NOD mice. CD4 ${ }^{+} \mathrm{CD} 62 \mathrm{~L}^{+}$are considered regulator cells, since they are able to prevent diabetes 
transfer in NOD-scid recipients [38] and their lower numbers in rachitic mice might contribute again to the more aggressive presentation of the disease.

Another interesting feature presented by the vitamin D-deficient NOD mice is their pattern of growth. Vitamin D-deficient NOD mice are lighter and smaller at 15 days of age but they reach the same weight as control mice around weaning at 30 days of age. This lower weight during the first days of life, probably due to the vitamin $\mathrm{D}$ deficiency of the dams, followed by a more rapid weight gain in the weeks thereafter might be another factor contributing to the diabetes presentation since also in humans, rapid growth and weight gain are implicated in Type 1 diabetes acceleration through increased metabolic demand [39, 40, 41].

Vitamin D deficiency not only affects the immune system, but it can also lead to beta-cell dysfunction. As shown previously, severe rickets leads to decreased insulin synthesis, insulin secretion and even overt insulin deficiency in vivo [42, 43, 44]. In the present study islets isolated from vitamin D-deficient mice at 100 days of age had an insulin synthetic and secretory capacity comparable to islets from control NOD mice. In vivo, however, clear glucose intolerance was observed already at 100 days of age in female and even more pronounced in male vitamin D-deficient NOD mice. There are several reports on the link between vitamin $\mathrm{D}$ deficiency and the pathogenesis of insulin resistance, impaired glucose intolerance and even Type 2 diabetes in humans $[45,46]$. Therefore the impaired glucose intolerance found in the vitamin Ddeficient NOD mice at 100 days of age might be explained in part by an increased insulin resistance in these animals, since insulin secretion and synthesis were comparable to those found in vitamin D-sufficient NOD mice.

Previously we have shown that in order to intervene with vitamin $D$ in vitamin $D$-sufficient mice in a preventive way, the use of regular vitamin $\mathrm{D}$ is insufficient [47] and long-term treatment with the activated form of the molecule, $1,25(\mathrm{OH})_{2} \mathrm{D}_{3}$, or a synthetic analogue is needed [48]. The use of $1,25(\mathrm{OH})_{2} \mathrm{D}_{3}$, and even of the synthetic analogues that have been designed to reduce the hypercalcaemic properties of the original molecule and to enhance its immune effects, still presents the danger of metabolic side effects, being hypercalcaemia and bone decalcification. These dangers are real, as chronic treatment with these products is necessary. At present several groups are considering dietary interventions using regular vitamin D supplements in early life in populations at risk for Type 1 diabetes. The effectiveness of these trials might be enhanced by selecting the trial subjects more carefully by measuring the vitamin $\mathrm{D}$ status of the subjects at baseline. Based on our data from NOD mice, we expect that giving vitamin $\mathrm{D}$ supplements to subjects with normal vitamin D levels could lack protective power, while preventing vitamin D deficiency in an at risk population might have dramatic effects on diabetes incidence. A weakness of our study is that we are unable to distinguish between the effects of vitamin $\mathrm{D}$ deficiency in utero or during the first weeks of life.

In conclusion, transient vitamin $\mathrm{D}$ deficiency in utero and in early life leads to a more aggressive presentation of Type 1 diabetes in NOD mice. An aberrant macrophage cytokine profile, a defect in $\mathrm{CD} 4{ }^{+} \mathrm{CD} 62 \mathrm{~L}^{+}$cells in combination with a higher islet inflammatory cytokine expression might trigger the disease more rapidly in mice genetically at risk. Vitamin D deficiency is thus an environmental factor that influences the expression of autoimmune Type 1 diabetes in NOD mice. If our NOD mouse data can be extrapolated to the human situation, preventing vitamin D deficiency in early life might be an easy and safe way to reduce the incidence of Type 1 diabetes.

Acknowledgments. This work was supported by grants of the KULeuven (GOA/99/10); the Flemish Research Foundation (Fonds Voor Wetenschappelijk Onderzoek [FWO] G.0084.02 and G.0233.04); a clinical research fellowship for C. Mathieu (FWO), a doctoral scholarship for A. Giulietti (KU Leuven) and a postdoctoral fellowship for C. Gysemans (FWO). This work was also conducted in collaboration with and supported by the JDRF Centre for Prevention of Beta Cell Destruction in Europe under grant number 4-2002-457. The excellent technical assistance of J. Laureys, J. Depovere, D. Valckx, S. Marcelis, E. Van Herck and I. Jans is gratefully acknowledged.

\section{References}

1. Akerblom HK, Vaarala O, Hyoty H, Ilonen J, Knip M (2002) Environmental factors in the etiology of type 1 diabetes. Am J Med Genet 115:18-29

2. Hyttinen V, Kaprio J, Kinnunen L, Koskenvuo M, Tuomilehto J (2003) Genetic liability of Type 1 diabetes and the onset age among 22,650 young Finnish twin pairs: a nationwide follow-up study. Diabetes 52:1052-1055

3. Green A, Patterson CC (2001) Trends in the incidence of childhood-onset diabetes in Europe 1989-1998. Diabetologia 44 [Suppl 3]:B3-B8

4. Ponsonby AL, McMichael A, Mei I van der (2002) Ultraviolet radiation and autoimmune disease: insights from epidemiological research. Toxicology 181-182:71-78

5. Serrano-Rios M, Goday A, Martinez LT (1999) Migrant populations and the incidence of type 1 diabetes mellitus: an overview of the literature with a focus on the Spanishheritage countries in Latin America. Diabetes Metab Res Rev 15:113-132

6. Feltbower RG, Bodansky HJ, McKinney PA, Houghton J, Stephenson CR, Haigh D (2002) Trends in the incidence of childhood diabetes in south Asians and other children in Bradford, UK. Diabet Med 19:162-166

7. Mathieu C, Van Etten E, Gysemans C et al. (2001) In vitro and in vivo analysis of the immune system of vitamin D receptor knockout mice. J Bone Miner Res 16:2057-2065

8. Van Etten E, Branisteanu DD, Overbergh L, Bouillon R, Verstuyf A, Mathieu C (2003) Combination of a 1,25-dihydroxyvitamin $\mathrm{D}(3)$ analog and a bisphosphonate prevents experimental autoimmune encephalomyelitis and preserves bone. Bone 32:397-404 
9. Tsuji M, Fujii K, Nakano T, Nishii Y (1994) 1 alpha-hydroxyvitamin D3 inhibits type II collagen-induced arthritis in rats. FEBS Lett 337:248-250

10. Larsson P, Mattsson L, Klareskog L, Johnsson C (1998) A vitamin D analogue (MC 1288) has immunomodulatory properties and suppresses collagen-induced arthritis (CIA) without causing hypercalcaemia. Clin Exp Immunol 114:277-283

11. Mathieu C, Waer M, Laureys J, Rutgeerts O, Bouillon R (1994) Prevention of autoimmune diabetes in NOD mice by 1,25 dihydroxyvitamin D3. Diabetologia 37:552558

12. Casteels KM, Mathieu C, Waer M et al. (1998) Prevention of type I diabetes in nonobese diabetic mice by late intervention with nonhypercalcemic analogs of 1,25-dihydroxyvitamin D3 in combination with a short induction course of cyclosporin A. Endocrinology 139:95-102

13. Mathieu C, Adorini L (2002) The coming of age of 1,25dihydroxyvitamin $\mathrm{D}(3)$ analogs as immunomodulatory agents. Trends Mol Med 8:174-179

14. The EURODIAB Substudy 2 Study Group (1999) Vitamin D supplement in early childhood and risk for Type I (insulin-dependent) diabetes mellitus. Diabetologia 42:5154

15. Stene LC, Ulriksen J, Magnus P, Joner G (2000) Use of cod liver oil during pregnancy associated with lower risk of Type I diabetes in the offspring. Diabetologia 43:10931098

16. Harris S (2002) Can vitamin D supplementation in infancy prevent type 1 diabetes? Nutr Rev 60:118-121

17. Hypponen E, Laara E, Reunanen A, Jarvelin MR, Virtanen SM (2001) Intake of vitamin D and risk of type 1 diabetes: a birth-cohort study. Lancet 358:1500-1503

18. Verhaeghe J, Van Herck E, Van Bree R, Van Assche FA, Bouillon R (1989) Osteocalcin during the reproductive cycle in normal and diabetic rats. J Endocrinol 120:143151

19. Gysemans C, Waer M, Laureys J et al. (2000) Islet xenograft destruction in the hu-PBL-severe combined immunodeficient (SCID) mouse necessitates anti-CD3 preactivation of human immune cells. Clin Exp Immunol 121:557-565

20. Mathieu C, Laureys J, Sobis H, Vandeputte M, Waer M, Bouillon R (1992) 1,25-Dihydroxyvitamin D3 prevents insulitis in NOD mice. Diabetes 41:1491-1495

21. Giulietti A, Overbergh L, Valckx D, Decallonne B, Bouillon R, Mathieu C (2001) An overview of real-time quantitative PCR: applications to quantify cytokine gene expression. Methods 25:386-401

22. Overbergh L, Valckx D, Waer M, Mathieu C (1999) Quantification of murine cytokine mRNAs using real time quantitative reverse transcriptase PCR. Cytokine 11:305312

23. Chesney RW (2002) Rickets: the third wave. Clin Pediatr (Phila) 41:137-139

24. Gale EA (2002) The rise of childhood type 1 diabetes in the 20th century. Diabetes 51:3353-3361

25. Bar-Shavit Z, Noff D, Edelstein S, Meyer M, Shibolet S, Goldman R (1981) 1,25-dihydroxyvitamin D3 and the regulation of macrophage function. Calcif Tissue Int 33:673-676

26. Stroder J, Kasal P (1970) Evaluation of phagocytosis in rickets. Acta Paediatr Scand 59:288-292

27. Wientroub S, Winter CC, Wahl SM, Wahl LM (1989) Effect of vitamin D deficiency on macrophage and lymphocyte function in the rat. Calcif Tissue Int 44:125130
28. Kankova M, Luini W, Pedrazzoni M et al. (1991) Impairment of cytokine production in mice fed a vitamin D3-deficient diet. Immunology 73:466-471

29. Jansen A, Homo-Delarche F, Hooijkaas H, Leenen PJ, Dardenne M, Drexhage HA (1994) Immunohistochemical characterization of monocytes-macrophages and dendritic cells involved in the initiation of the insulitis and beta- cell destruction in NOD mice. Diabetes 43:667-675

30. Rosmalen JG, Martin T, Dobbs C et al. (2000) Subsets of macrophages and dendritic cells in nonobese diabetic mouse pancreatic inflammatory infiltrates: correlation with the development of diabetes. Lab Invest 80:2330

31. Serreze DV, Gaskins HR, Leiter EH (1993) Defects in the differentiation and function of antigen presenting cells in NOD/Lt mice. J Immunol 150:2534-2543

32. Alleva DG, Pavlovich RP, Grant C, Kaser SB, Beller DI (2000) Aberrant macrophage cytokine production is a conserved feature among autoimmune-prone mouse strains: elevated interleukin (IL)-12 and an imbalance in tumor necrosis factor-alpha and IL-10 define a unique cytokine profile in macrophages from young nonobese diabetic mice. Diabetes 49:1106-1115

33. Waldmann TA (2002) The IL-2/IL-15 receptor systems: targets for immunotherapy. J Clin Immunol 22:51-56

34. O'Brien BA, Huang Y, Geng X, Dutz JP, Finegood DT (2002) Phagocytosis of apoptotic cells by macrophages from NOD mice is reduced. Diabetes 51:24812488

35. Bradley LM, Asensio VC, Schioetz LK et al. (1999) Islet-specific Th1, but not Th2, cells secrete multiple chemokines and promote rapid induction of autoimmune diabetes. J Immunol 162:2511-2520

36. Chen MC, Proost P, Gysemans C, Mathieu C, Eizirik DL (2001) Monocyte chemoattractant protein-1 is expressed in pancreatic islets from prediabetic NOD mice and in interleukin-1 beta-exposed human and rat islet cells. Diabetologia 44:325-332

37. Cardozo AK, Proost P, Gysemans C, Chen MC, Mathieu C, Eizirik DL (2003) IL-1beta and IFN-gamma induce the expression of diverse chemokines and IL-15 in human and rat pancreatic islet cells, and in islets from pre- diabetic NOD mice. Diabetologia 46:255-266

38. Herbelin A, Gombert JM, Lepault F, Bach JF, Chatenoud L (1998) Mature mainstream TCR alpha beta+CD4+ thymocytes expressing L-selectin mediate "active tolerance" in the nonobese diabetic mouse. J Immunol 161:26202628

39. Weets I, Van Autreve J, Van der Auwera BJ et al. (2001) Male-to-female excess in diabetes diagnosed in early adulthood is not specific for the immune-mediated form nor is it HLA-DQ restricted: possible relation to increased body mass index. Diabetologia 44:40-47

40. Bruining GJ (2000) Association between infant growth before onset of juvenile type-1 diabetes and autoantibodies to IA-2. Netherlands Kolibrie study group of childhood diabetes. Lancet 356:655-656

41. Hypponen E, Virtanen SM, Kenward MG, Knip M, Akerblom HK (2000) Obesity, increased linear growth, and risk of type 1 diabetes in children. Diabetes Care 23:1755-1760

42. Gedik O, Akalin S (1986) Effects of vitamin D deficiency and repletion on insulin and glucagon secretion in man. Diabetologia 29:142-145

43. Kadowaki S, Norman AW (1984) Dietary vitamin D is essential for normal insulin secretion from the perfused rat pancreas. J Clin Invest 73:759-766 
44. Nyomba BL, Bouillon R, De Moor P (1984) Influence of vitamin $\mathrm{D}$ status on insulin secretion and glucose tolerance in the rabbit. Endocrinology 115:191-197

45. Baynes KC, Boucher BJ, Feskens EJ, Kromhout D (1997) Vitamin D, glucose tolerance and insulinaemia in elderly men. Diabetologia 40:344-347

46. Boucher BJ (1998) Inadequate vitamin D status: does it contribute to the disorders comprising syndrome ' $\mathrm{X}$ '? Br J Nutr 79:315-327
47. Mathieu C, Van Etten E, Gysemans C, Decallonne B, Bouillon R (2002) Seasonality of birth in patients with type 1 diabetes. Lancet 359:1248

48. Mathieu C, Waer M, Casteels K, Laureys J, Bouillon R (1995) Prevention of type I diabetes in NOD mice by nonhypercalcemic doses of a new structural analog of 1,25dihydroxyvitamin D3, KH1060. Endocrinology 136:866872 